\title{
Construction of a Plasmid for High Level Expression of XMP Aminase in Escherichia coli
}

\author{
Akihiko Maruyama, Tatsunari Nishi, Akio Ozaki,* \\ Seiga Ito and Tatsuro FujIo \\ Tokyo Research Laboratories, Kyowa Hakko Kogyo Co., Ltd., \\ 3-6-6, Asahimachi, Machida-shi, Tokyo 194, Japan \\ Received February 10, 1986
}

\begin{abstract}
In order to produce $5^{\prime}$-guanylic acid (GMP) from $5^{\prime}$-xanthylic acid (XMP), we attempted to increase the activity of the conversion enzyme, XMP aminase (EC 6.3.4.1), in Escherichia coli. We subcloned the guaA gene coding for XMP aminase from plasmid pLC34-10 into pBR322. By connecting the tryptophan (trp) promoter at a suitable position upstream of the guaA gene, we obtained plasmid pXAR33. E. coli K294/pXAR33 showed an increase in activity of approximately 80 times when compared with $\mathrm{K} 294$, and the amount of the enzyme protein represented approx. $10 \%$ of the total cellular protein. The production of GMP with the plasmid carrying strain was also investigated.
\end{abstract}

GMP, similar to $5^{\prime}$-inosinic acid (IMP), is widely used for flavoring. Both compounds show synergistic flavoring with monosodium glutamate (MSG), ${ }^{1)}$ and the synergistic effect of GMP was reported to be 3.8 times that of IMP. ${ }^{2)}$ Methods for industrial production of GMP include 1) enzymatic degradation of RNA extracted from yeast, ${ }^{2}{ }^{2}$ 2) chemical conversion of a precursor, 5'-amino-4-imidazole carboxamide riboside (AICA-R) or guanosine, both of which are produced through fermentation, ${ }^{3,4)}$ and 3) enzymatic amination of XMP produced through fermentation. ${ }^{5}$ )

We have investigated the production of GMP with method 3). This method consists of 2 separate processes: firstly, XMP is produced by a mutant strain of Brevibacterium ammoniagenes, ${ }^{6}$ ) and secondly, the XMP is converted to GMP with another mutant strain of $B$. ammoniagenes as the enzyme source. ${ }^{5)}$ The mutant strain used for the conversion reaction is resistant to decoyinine and shows an increased level of XMP aminase, which is the enzyme that converts XMP to GMP. ${ }^{7)}$ By increasing the activity of this enzyme, a reduction in the total amount of cells required for the conversion reaction is expected when whole cells are used as the enzyme source, and at the same time reduction to a minimum of the production of degradation products and by-products such as GDP and GTP is also expected. We therefore attempted to obtain XMP aminase-overproducing strains of $E$. coli using genetic engineering techniques.

The guaA gene coding for XMP aminase is located at $54 \mathrm{~min}$ on the $E$. coli chromosomal map, and forms one operon together with the guaB gene coding for IMP dehydrogenase. ${ }^{8}$ The genes are arranged in the order of guaPO, $g u a B$ and guaA, and it is known that a secondary promoter for the guaA gene of low efficiency exists upstream of the guaA gene.9)

Recently, the total DNA sequence of the guaAB operon was determined. ${ }^{10,11)}$ It has become apparent that the guaB and guaA gene products have 511 and 525 amino acid residues, respectively, and that between the two structural genes there lies a 68-bp inter-

* Present address: Technical Research Laboratories, Kyowa Hakko Kogyo Co., Ltd., 1-1, Kyowamachi, Hofu-shi, Yamaguchi, Japan. 
cistronic region.

Our work was independent of this DNA sequencing study, involving the subcloning of the guaA gene from the Clarke and Carbon gene bank ${ }^{12)}$ into pBR322 and the construction of a plasmid for high level expression of XMP aminase utilizing the trp promoter. The enzymatic production of GMP from XMP with cells of the XMP aminase-overproducing strain as the enzyme source is also reported.

\section{MATERIALS AND METHODS}

Plasmids and bacterial strains. E. coli strain JA 200 containing pLC34-10 ${ }^{13)}$ was obtained from the E. coli Genetic Stock Center. Plasmids pGBK3 and pGBY1, used in this study, were constructed by Nishi et al. for the expression of human interferon- $\gamma$ (HuIFN- $\gamma$ ). pGBK3 consists of the following four fragments (Fig. 2); a $3.7 \mathrm{~kb}$ EcoRI-Sall fragment of pBR322, ${ }^{14)}$ a $0.37-\mathrm{kb}$ EcoRIHindIII trp promoter fragment of pKYP10, ${ }^{15)}$ a $0.85-\mathrm{kb}$ HindIII-BamHI HuIFN- $\gamma$-cDNA-containing fragment derived from pGKA2 ${ }^{16)}$ and a $0.95-\mathrm{kb}$ Bam HI-Sal I lipoprotein-terminator-containing fragment of pIN-IIA2. ${ }^{17)}$ pGBY1 was constructed as follows; the NruI site within the tetracycline-resistance gene of pGBK 3 derived from pBR322 was converted to a $B g l \mathrm{II}$ site with a $B g l \mathrm{II}$ linker. As pGBY1 has a similar structure to pGBK3 (Fig. 2), for this study any difference between these two plasmids can be ignored. E. coli strain $\mathrm{K}_{2} 24$ (indoI ${ }^{-}, \mathrm{B}_{1}^{-}$, $\left.\mathrm{r}_{\mathrm{k}}^{-}, \mathrm{m}_{\mathrm{k}}^{+}\right)^{18)}$ was used mainly as the host for the expression of XMP aminase. Strains PL1068 ( $\left.\mathrm{guaA}^{-}\right)^{19)}$ and KLC421 $\left(\mathrm{guaA}^{-}, \mathrm{guaB}^{-}\right)^{20)}$ were used to confirm the presence of the guaA gene on the plasmid.

Enzymes and reagents. The restriction enzymes were obtained from Takara Shuzo Co., Ltd. (Kyoto, Japan), and used in the buffers under the conditions recommended by the supplier. The E. coli DNA polymerase I Klenow fragment and Bal31 exonuclease were obtained from Bethesda Research Laboratories Inc., and T4 DNA ligase from Takara Shuzo Co., Ltd. The buffer solutions used for the reactions were as follows, DNA polymerase buffer: $50 \mathrm{~mm}$ Tris-HCl, pH 7.6, $7 \mathrm{mM} \mathrm{MgCl}_{2}, 6 \mathrm{~mm}$ 2-mercaptoethanol, and $0.5 \mathrm{~mm}$ dATP, dCTP, dGTP and dTTP; Bal31 buffer: $20 \mathrm{~mm}$ Tris- $\mathrm{HCl}$, pH $8.1,600 \mathrm{~mm} \mathrm{NaCl}$, $12 \mathrm{~mm} \mathrm{CaCl}, 12 \mathrm{~mm} \mathrm{MgCl}_{2}$ and $1 \mathrm{~mm}$ EDTA; and ligation buffer: $20 \mathrm{~mm}$ Tris- $\mathrm{HCl}, \mathrm{pH}$ 7.6, $10 \mathrm{mM} \mathrm{MgCl}_{2}, 10 \mathrm{~mm}$ dithiothreitol and $0.5 \mathrm{~mm}$ ATP.

Plasmid DNA preparation and fragment purification. Plasmid DNA was prepared according to the method of Birnboim and Doly. ${ }^{21)}$ DNA fragments were purified using low-gelling temperature (LGT) agarose gel (Sigma type VII) as described by Wieslander. ${ }^{22)}$

Transformation. The E. coli $\mathrm{K}-12$ strains were transformed by the method of Cohen et al. ${ }^{23)}$

Media. The following 2 types of medium were used for culturing E. coli, L medium: $10 \mathrm{~g} /$ liter Bacto-tryptone, $5 \mathrm{~g} /$ liter yeast extract, $5 \mathrm{~g}$ /liter $\mathrm{NaCl}, \mathrm{pH} 7.2$; and $\mathrm{M} 9$ medium: $6 \mathrm{~g}$ /liter $\mathrm{Na}_{2} \mathrm{HPO}_{4}, 3 \mathrm{~g} /$ liter $\mathrm{KH}_{2} \mathrm{PO}_{4}, 5 \mathrm{~g} /$ liter $\mathrm{NaCl}, 1 \mathrm{~g} /$ liter $\mathrm{NH}_{4} \mathrm{Cl}, 3 \mathrm{~g} /$ liter glucose, $4 \mathrm{mg} /$ liter vitamin $\mathrm{B}_{1}, 0.25 \mathrm{~g} /$ liter $\mathrm{MgSO}_{4} \cdot 7 \mathrm{H}_{2} \mathrm{O}$ and $2 \mathrm{~g} /$ liter casamino acids. To both was added $20 \mathrm{mg} /$ liter tetracycline or $50 \mathrm{mg} /$ liter ampicillin, if necessary. The seed size was $1 \sim 5 \%$, and the cultivations were carried out at $30^{\circ} \mathrm{C}$ for $10 \sim 18 \mathrm{hr}$.

Measurement of XMP aminase activity. The enzyme activity was measured by the method of Sakamoto ${ }^{24)}$ with slight modification. After collecting the $E$. coli cells by centrifugation, they were suspended in a $1 / 10$ volume of water, and then after adding $20 \mathrm{ml} /$ liter of toluene and shaking for $20 \mathrm{~min}$ at $37^{\circ} \mathrm{C}$, the activity was measured. The reaction mixture was as follows: $160 \mathrm{~mm}$ Tris- $\mathrm{HCl}, \mathrm{pH} 8.6$, $12 \mathrm{~mm}$ ATP, $23 \mathrm{~mm}$ XMP, $16 \mathrm{mM} \mathrm{MgSO}_{4} \cdot 7 \mathrm{H}_{2} \mathrm{O}, 40 \mathrm{~mm}$ $\left(\mathrm{NH}_{4}\right)_{2} \mathrm{SO}_{4}$ and the above toluene-treated cells, the total volume being adjusted to $1.25 \mathrm{ml}$. The reaction mixture was shaken in a test-tube at $42^{\circ} \mathrm{C}$, and after reaction for $15 \mathrm{~min}, 0.1 \mathrm{ml}$ was taken and after mixing with $3.9 \mathrm{ml}$ of $3.5 \%$ perchloric acid, centrifuged at $1,600 \times g$ for $10 \mathrm{~min}$. The absorbance at $290 \mathrm{~nm}$ of the supernatant was measured. Under these conditions the increase in absorbance at $290 \mathrm{~nm}$ reflects the formation of GMP. The molar extinction coefficient of GMP was taken to be $6.0 \times 10^{3}$. One unit of enzyme is defined as the amount of enzyme which catalyzes the formation of $1 \mu \mathrm{mol}$ of GMP per minute under the above conditions.

SDS-Polyacrylamide gel electrophoresis. SDS-Polyacrylamide gel electrophoresis was performed according to the method of Laemmli. ${ }^{25)}$ After the samples had been heat-treated $\left(100^{\circ} \mathrm{C}, 2 \mathrm{~min}\right)$ in Tris- $\mathrm{HCl}$ buffer $(\mathrm{pH}$ 6.8) containing $2 \%$ SDS, the proteins were separated on a SDS-polyacrylamide slab gel $(14 \times 15 \times 0.1 \mathrm{~cm})$. The acrylamide concentration of the separation gel was $12 \%$. After staining the gel with Coomassie Brilliant Blue, the amount of protein was determined with a Shimadzu CS930 chromato-scanner.

Quantitative analysis of the constituents. In the conversion reaction, each constituent was analysed as follows: XMP and GMP were measured by paper chromatography ${ }^{5)}$ and high performance liquid chromatography (HPLC). The conditions for HPLC were as follows: column, Partisil 10 SAX $4.6 \mathrm{~mm} \times 250 \mathrm{~mm}$ (Whatman); detection, $254 \mathrm{~nm}$; solvent, $0.05 \mathrm{M} \mathrm{KH}_{2} \mathrm{PO}_{4}(\mathrm{pH} 4.0$ ); column temperature, $50^{\circ} \mathrm{C}$; and flow rate, $2.0 \mathrm{ml} / \mathrm{min}$. ATP was measured using an assay kit, ATP test, purchased from Boehringer-Mannheim. The conditions for the con- 
version reaction are given in the legend to Fig. 4.

\section{RESULTS}

Subcloning of the guaA gene into $p B R 322$

The source of the guaA gene we used was a hybrid plasmid consisting of the gua operon and col-E $E_{1}$ DNA, pLC34-10, ${ }^{13)}$ which was obtained from the Clarke and Carbon gene bank $^{12)}$ by courtesy of Dr. B. J. Bachmann. The size of pLC34-10 is approximately $15 \mathrm{~kb}$, as shown in Fig. 1, and according to Takagi et $a l .{ }^{26)}$ it was assumed that the guaA gene is located on the approx. $7 \mathrm{~kb}$ long EcoRI-Pst I fragment, which includes a PstI site. We connected this segment to the EcoRI-PstI segment of pBR322 and transformed E. coli strain

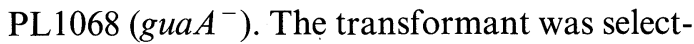
ed according to its tetracycline resistance and lack of guanine requirement. The growth of $E$. coli strain KLC421 (guaA ${ }^{-}$, guaB $\left.{ }^{-}\right)$, which had been transformed with the plasmid, pXA1 (approx. $11 \mathrm{~kb}$ ), thus obtained, was observed on the M9 medium. Growth was seen on medium containing $5 \mathrm{mg} /$ liter xanthine or guanine but not on medium containing $5 \mathrm{mg} /$ liter hypoxanthine. This indicates that in pXA1, only the guaA gene is being expressed.

\section{Insertion of a trp promoter upstream of guaA}

In strains containing pXA1, an apparent increase in XMP aminase activity was not seen when compared with pLC34-10. The reason for this is thought to be that whereas in pLC34-10 the guaA gene is transcribed from the main promoter, in pXA1 it is transcribed from the secondary promoter with weak transcriptional activity, and so the increase in copy number caused by subcloning into pBR322 is cancelled out. We therefore attempted to insert a trp promoter with strong transcriptional activity upstream of the guaA gene (Fig. 2). We used pGBK3, constructed by Nishi et al., as the source of the trp promoter (See Materials And Methods). By joining the HindIII-MluI fragment containing the guaA gene from pXA1 and the HindIII-MluI fragment containing the trp promoter from

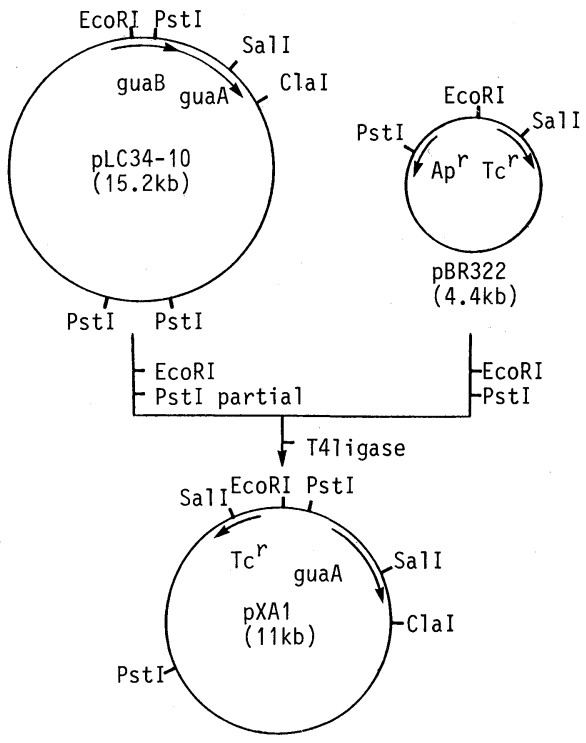

FIG. 1. Subcloning of the guaA Gene.

Abbreviations: $\mathrm{Ap}^{\mathrm{r}}$, resistance against ampicillin; $\mathrm{Tc}^{\mathrm{r}}$, resistance against tetracycline.

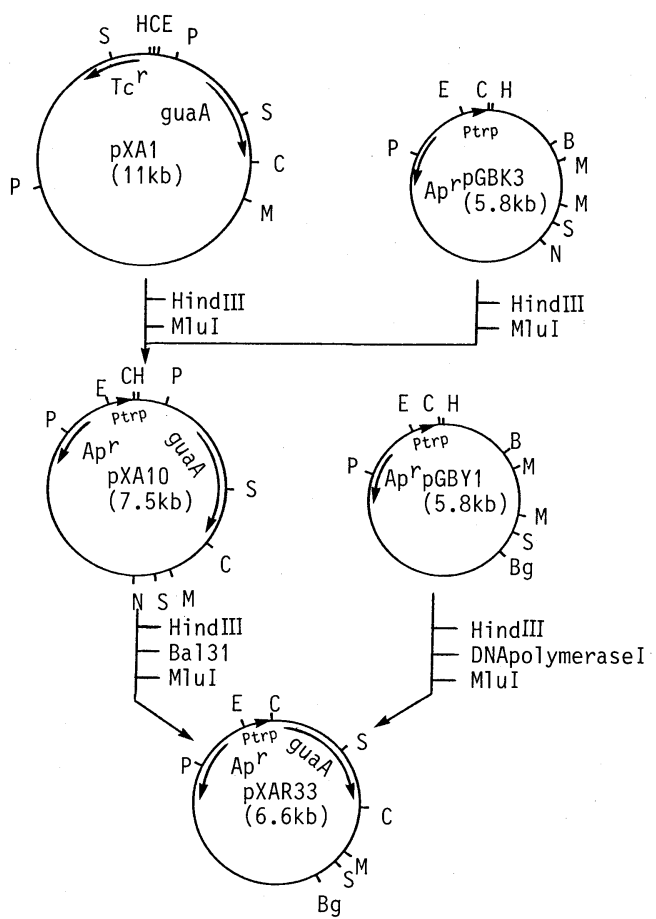

Fig. 2. Construction of Plasmids showing High Level Expression of XMP Aminase.

Abbreviations: Ptrp, tryptophan promoter; E, Eco RI; C, ClaI; H, HindIII; P, Pst I; M, MluI; B, Bam HI; N, NruI; $\mathrm{S}, \mathrm{SalI}$; Bg, $B g l \mathrm{II}$. 
pGBK3, we constructed pXA10.

\section{Shortening of the trp promoter-guaA interval}

An increase in XMP aminase activity was not seen in the pXA10-carrying strain, either. This was supposed to be because the distance between the trp promoter and the guaA structural gene was too great. We therefore digested the upstream region of the guaA gene, through treatment with Bal31, from the HindIII site of pXA10. After digestion with MluI, the fragment containing the guaA gene was ligated to the fragment containing the trp promoter obtained from pGBY1 (Fig. 2).

When the 97 strains thus transformed to ampicillin resistance were tested as to XMP aminase activity, 22 showed marked increases and 47 showed similar levels of activity to those of the pXA10-carrying strains, whereas the remaining 28 showed the same low level of activity as the host strain (K294). When the plasmid which showed the highest activity, pXAR33, was analyzed, it was found that approx. $0.9 \mathrm{~kb}$ of the DNA had been deleted from the HindIII site of pXA10. In strains which showed similar levels of activity to $\mathrm{K} 294$, over $1.3 \mathrm{~kb}$ of the DNA had been deleted.

\section{Comparison of activities}

Table I shows the XMP aminase activities of the bacterial strains obtained in this study. In the strain containing pLC34-10, a 13.6-fold increase in activity compared with the host strain was observed. In pXA1, in which only the guaA gene was subcloned into pBR322, and pXA10, in which a trp promoter was inserted upstream of the guaA gene, an apparent increase in activity was not observed. However, in pXAR33, in which the distance between the trp promoter and guaA gene had been shortened, the activity had increased by over 4 times when compared with that of the strain carrying pLC34-10 (by approx. 80 times when compared with the host strain).

Figure 3 shows the SDS-polyacrylamide gel electrophoresis patterns of these bacterial strains. In the strain carrying pXAR33, which
Table I. XMP Aminase Activities in Strains Carrying Various Plasmids

\begin{tabular}{llcr}
\multicolumn{1}{c}{ Host } & Plasmid & Activity $(\mathrm{U} / \mathrm{g})^{*}$ & Ratio \\
\hline K294 & - & 0.88 & 1.0 \\
PL1068 & pLC34-10 & 11.96 & 13.6 \\
K294 & pXA1 & 17.08 & 19.4 \\
K294 & pXA10 & 16.91 & 19.2 \\
K294 & pXAR33 & 73.50 & 83.5 \\
\hline
\end{tabular}

* Units per gram cells (wet weight).

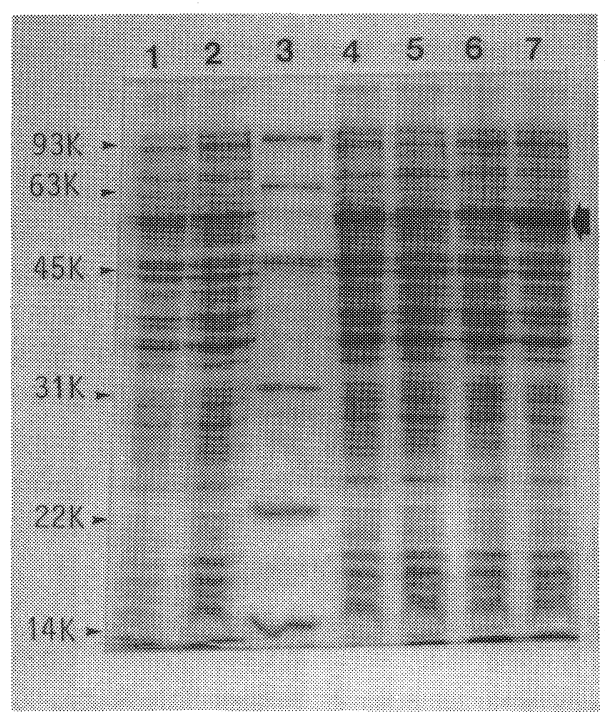

FIG. 3. SDS-Polyacrylamide Gel Electrophoresis of Proteins Synthesized by the various $E$. coli Strains.

The $E$. coli strains were grown in M9 medium for $16 \mathrm{hr}$ at $30^{\circ} \mathrm{C}$. Lane 1, K294; lane 2, PL1068; lane 3, size markers; lane 4, PL1068/pLC34-10; lane 5, K294/pXA1; lane 6, K294/pXA10; lane 7, K294/pXAR33. The arrow indicates the position of XMP aminase.

showed the highest activity (lane 7), a dark band with an apparent molecular weight of around $58 \mathrm{~K}$ was observed. Considering that the molecular weight, as calculated from the DNA sequence, is 58,604 daltons, ${ }^{11)}$ it was thought likely that this band represented XMP aminase. The proportion of XMP aminase to total cellular protein was calculated from the optical density of the stained gel, and was found to reach approx. $10 \%$ in the pXAR33carrying strain. 


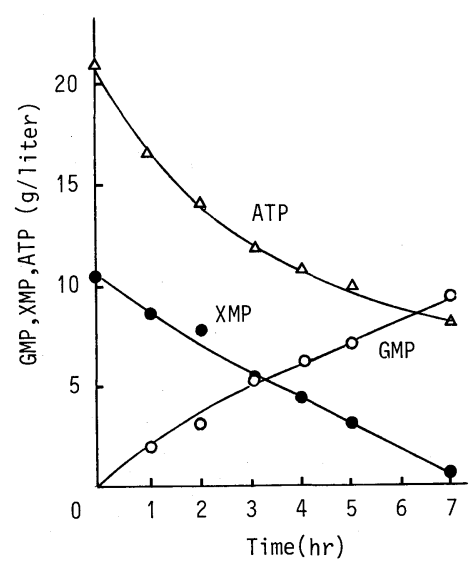

FIG. 4. Time Course of the Conversion Reaction.

The reaction mixture consisted of $20 \mathrm{~g} /$ liter $\mathrm{ATP} \cdot \mathrm{Na}_{2}$. $3 \mathrm{H}_{2} \mathrm{O}, \quad 10 \mathrm{~g} /$ liter $\mathrm{XMP} \cdot \mathrm{Na}_{2} \cdot 7 \mathrm{H}_{2} \mathrm{O}, \quad 5 \mathrm{~g} /$ liter $\quad \mathrm{MgSO}_{4}$. $7 \mathrm{H}_{2} \mathrm{O}$ and $0.62 \mathrm{~g} /$ liter toluene-treated cells (wet weight). The reaction was carried out in a volume of $30 \mathrm{ml}$ in a $200-\mathrm{ml}$ beaker at $42^{\circ} \mathrm{C}$, with stirring at $900 \mathrm{rpm}$ with a magnetic stirrer and with the $\mathrm{pH}$ controlled at 7.4 with $3 \mathrm{~N}$ $\mathrm{NaOH}$.

\section{Use of the XMP aminase-overproducing strain as the enzyme source}

We investigated as to whether or not the whole cells of the XMP aminase-overproducing strain could be utilized as the enzyme source for the enzymatic conversion of XMP to GMP. In order to use whole cells as an enzyme source, it is necessary to make the cytoplasmic membrane permeable to nucleotides, since XMP, ATP and GMP should be able to move freely in and out of the cells during the reaction. We therefore tested toluene-treatment as follows. E. coli strain K294 carrying pXAR33 was cultured for 16 hours at $39^{\circ} \mathrm{C}$ in $\mathrm{M} 9$ medium. After collecting the cells by centrifugation and suspending them in a $1 / 10$ volume of water, $20 \mathrm{ml} /$ liter toluene was added and the mixture was stood for $20 \mathrm{~min}$ at $37^{\circ} \mathrm{C}$. These toluene-treated cells were used as the enzyme source as described in the legend to Fig. 4. Figure 4 shows the time course of the reaction. After 7 hours, the initial XMP had completely disappeared, and the conversion ratio from XMP to GMP was over $90 \%$.

\section{DISCUSSION}

In order to express a large amount of XMP aminase, it was found useful to connect a promoter with strong transcriptional activity such as the trp promoter at a suitable position upstream of the guaA gene. The strain carrying pXAR33 showed the highest activity, and the distance between the trp promoter and the guaA gene of pXAR33 was shortened most by Bal31 among the plasmids isolated from the 22 strains which showed marked increases in activity as compared with the pXA10-carrying strain. When we compared the DNA sequence $^{11)}$ and the restriction analysis data of pXAR33 (data not shown), it was found that the guaA-containing fragment of pXA10 had been digested by Bal31 from the HindIII site up to approx. $80 \mathrm{bp}$ upstream from the initiation codon of guaA. In other words, it could be assumed that the $68 \mathrm{bp}$ intercistronic region had been retained.

In the strain carrying pXAR33, an amount of XMP aminase corresponding to approx. $10 \%$ of the toral cellular protein was produced. The production of a large amount of a specific enzyme in this way is extremely useful for the use of whole cells as the source of a certain enzyme in the enzymatic production of useful compounds, since it is possible to reduce the formation of the by-products (for example, GDP and GTP in this case) and degradation products (for example, guanosine, guanine, xanthosine, xanthine, etc. in this case), which are formed through the catalysis by other enzymes contained in the cells.

We are at present investigating the possibility of using a promoter showing high transcriptional activity such as the lambda phage $\mathrm{P}_{\mathrm{L}}$ promoter or an ATG vector ${ }^{27)}$ in order to obtain a bacterium with higher activity. In this report we discussed the construction of a plasmid showing high level expression of XMP aminase, and the use of strains containing the plasmid as the enzyme source. However, the conversion from XMP to GMP involves a reaction system which consumes ATP and so, in order to establish a 
practical GMP production process, it is necessary to devise a practical method of supplying ATP. We are therefore planning to examine the possibility of developing a GMP-producing process consisting of a coupling reaction involving XMP aminase and an ATP regeneration system.

Acknowledgment. The authors wish to thank Miss Eriko Okajima for her helpful technical assistance.

\section{REFERENCES}

1) A. Kuninaka, Nippon Nôgeikagaku Kaishi, 34, 489 (1960).

2) A. Kuninaka, M. Kibi and K. Sakaguchi, Food Technol., 18, 287 (1964).

3) K. Kinoshita, T. Shiro, A. Yamazaki, I. Kumashiro, T. Takenishi and T. Tsunoda, Biotechnol. Bioeng., 9, 329 (1967).

4) H. Matsui, K. Sato, H. Enei and Y. Hirose, Agric. Biol. Chem., 43, 1739 (1979).

5) T. Fujio, Y. Kotani and A. Furuya, J. Ferment. Technol., 62, 131 (1984).

6) M. Misawa, T. Nara, K. Udagawa, S. Abe and S. Kinoshita, Agric. Biol. Chem., 33, 370 (1969).

7) A. Furuya, R. Okachi, K. Takayama and S. Abe, Biotechnol. Bioeng., 15, 795 (1973).

8) K. Shimada, Y. Fukumaki and Y. Takagi, Mol. Gen. Genet., 147, 203 (1976).

9) Y. Fukumaki, K. Shimada and Y. Takagi, J. Bacteriol., 131, 685 (1977).

10) A. A. Tiedeman and J. M. Smith, Nuc. Acids Res.,
13, 1303 (1985).

11) A. A. Tiedeman, J. M. Smith and H. Zalkin, J. Biol. Chem., 260, 8676 (1985).

12) L. Clarke and J. Carbon, Cell, 9, 91 (1976).

13) F. C. Neidhardt, V. Vaughn, T. A. Phillips and P. L. Bloch, Microbiol. Rev., 47, 231 (1983).

14) F. Bolivar, R. L. Rodriguez, P. J. Greene, M. C. Betlach, H. L. Heyneker and H. W. Boyer, Gene, 2, 95 (1977).

15) T. Nishi, A. Saito, T. Oka, S. Ito, C. Takaoka and T. Taniguchi, Agric. Biol. Chem., 48, 669 (1984).

16) T. Nishi, T. Fujita, C. Nishi-Takaoka, A. Saito, T. Matsumoto, M. Sato, T. Oka, S. Ito, Y. M. Yip, J. Vilcek and T. Taniguchi, J. Biochem., 97, 153 (1985).

17) K. Nakamura and M. Inouye, The EMBO J., 1, 771 (1982).

18) K. Backman, M. Ptashne and W. Gilbert, Proc. Natl. Acad. Sci. U.S.A., 73, 4174 (1976).

19) P. R. Lambden and W. T. Drabble, J. Bacteriol., 115, 992 (1973).

20) L. D. Vales, J. W. Chase and J. B. Murphy, J. Bacteriol., 139, 320 (1979).

21) H. C. Birnboim and J. Doly, Nuc. Acids Res., 7, 1513 (1979).

22) L. Wieslander, Anal. Biochem., 98, 305 (1979).

23) S. N. Cohen, A. C. Y. Chang and L. Hsu, Proc. Natl. Acad. Sci. U.S.A., 69, 2110 (1972).

24) N. Sakamoto, Methods in Enzymology, 51, 213 (1978).

25) U. K. Laemmli, Nature, 227, 680 (1970).

26) S. Maeda, K. Shimada and Y. Takagi, Biochem. Biophys. Res. Commun., 72, 1129 (1976).

27) T. Nishi, M. Sato, A. Saito, S. Ito, C. Takaoka and T. Taniguchi, $D N A, 2,265$ (1983). 